\title{
Effectiveness of partially hydrolyzed rice glutelin as a food emulsifier: comparison to whey protein
}

\author{
Xingfeng Xu ${ }^{\mathrm{a}, \mathrm{b}}$, Junzhen Zhong ${ }^{\mathrm{a}}$, Jun Chen ${ }^{\mathrm{a}}$, Chengmei Liu ${ }^{\mathrm{a}, 1^{*}}$, Liping Luo ${ }^{\mathrm{a}}$, \\ Shunjing Luo ${ }^{a}$, Lixin $\mathrm{Wu}^{\mathrm{c}}$, David Julian McClements ${ }^{\mathrm{b}, \mathrm{d}, 1^{* *}}$
}

${ }^{a}$ State Key Laboratory of Food Science and Technology, Nanchang University, Nanchang, No. 235 Nanjing East Road, Nanchang 330047, Jiangxi, China.

${ }^{b}$ Department of Food Science, University of Massachusetts, Amherst, MA 01003, USA.

${ }^{c}$ Golden Agriculture Biotech Company Limited, No. 100 Xinzhou Road, Nanchang 330000, Jiangxi, China

${ }^{d}$ Department of Biochemistry, Faculty of Science, King Abdulaziz University, P. O. Box 80203, Jeddah, 21589, Saudi Arabia

Journal: Food Chemistry

Submitted: March 6, 2016

Running title: Hydrolyzed rice glutelin as emulsifier: Comparison to whey protein

\section{Email address:}


Xingfeng Xu: jiaonanxuxingfeng@126.com

Junzhen Zhong: zhongjunzhen@163.com

Jun Chen: chen-jun1986@ hotmail.com

Liping Luo: 1luo2@126.com

Shunjing Luo: luoshunjing@aliyun.com

Lixin Wu:wulixin@gabchina.com

* Corresponding author: State Key Laboratory of Food Science and Technology, Nanchang University, Nanchang, Jiangxi 330047, China; liuchengmei@aliyun.com (C. Liu); Tel: +86 $79188305872(8106)$; Fax: +86 79188334509

** Corresponding author: Department of Food Science, University of Massachusetts, Amherst, MA 01003, USA; mcclements@foodsci.umass.edu (D.J. McClements); Tel.: +1 (413) 545 1019; fax: +1 (413) 5451262.

${ }^{1}$ These authors contributed equally to this manuscript 


\section{Abstract}

The emulsifying properties of partially hydrolyzed rice glutelin (H-RG, 2\% degree of hydrolysis) were compared to those of whey isolate protein (WPI), a commonly used protein-based emulsifier. The surface load of WPI (1\% emulsifier, $\left.d_{32}=167.5 \mathrm{~nm}\right)$ was 2.8 times lower than that of $\mathrm{H}-\mathrm{RG}\left(3 \%\right.$ emulsifier, $\left.\mathrm{d}_{32}=159.0 \mathrm{~nm}\right)$. Emulsions containing WPI-coated lipid droplets had better stability to $\mathrm{pH}$ changes (2-8), $\mathrm{NaCl}$ addition $(0-500 \mathrm{mM})$ and thermal processing $\left(30-90{ }^{\circ} \mathrm{C}, 0\right.$ or $200 \mathrm{mM}$ $\mathrm{NaCl}$ ). Nevertheless, $\mathrm{H}-\mathrm{RG}$ emulsions were stable over a range of conditions: $\mathrm{pH}$ 6-8; $\mathrm{NaCl} \leq 200(\mathrm{pH} 7)$; temperatures $\leq 90{ }^{\circ} \mathrm{C}$ in the absence of salt $(\mathrm{pH} 7)$; and temperatures $\leq 50{ }^{\circ} \mathrm{C}$ in the presence of $200 \mathrm{mM} \mathrm{NaCl}(\mathrm{pH} 7)$. This study indicates that $\mathrm{H}-\mathrm{RG}$ may be utilized as a natural emulsifier in the development of label-friendly emulsion-based food products, but that further work is needed to increase the range of applications.

Keywords: rice glutelin; whey protein isolate; emulsion; environmental stress; stability. 


\section{Introduction}

Many kinds of commonly consumed food products are emulsions, such as dairy creamers, dressings, dips, sauces and soft drinks (Dickinson, 2003). Emulsifiers are one of the most important additives for creating stable food emulsions. There are two major categories of emulsifiers used in the food industry: small-molecule surfactants (e.g., Tween-80, monoglycerides, and lecithin) and large-molecule surfactants (e.g., protein and polysaccharides) (Charoen, Jangchud, Jangchud, Harnsilawat, Naivikul, \& McClements, 2011; Ozturk, Argin, Ozilgen, \& McClements, 2015). Nowadays, consumers are becoming more interested in having food products with "clean" labels, which can be achieved by replacing synthetic or animal-based emulsifiers with plant-based ones (Ozturk, Argin, Ozilgen, \& McClements, 2015).

Food proteins are effective emulsifiers, because of their amphiphilic nature, relatively large molecular dimensions, and relatively high electrical charge (Dickinson, 2003; McClements, 2004). Consequently, they can adsorb to oil droplet surfaces during homogenization, and form coatings that protect droplets against aggregation by generating strong repulsive interactions (e.g., steric and electrostatic repulsion). Whey proteins and caseins are the most commonly used protein-based emulsifiers in foods (Khouryieh, Puli, Williams, \& Aramouni, 2015). However, because of their potential allergenicity (Do, Williams, \& Toomer, 2016) and their unsuitability for utilization in vegan products, there is a demand for more label friendly plant-based alternatives. Rice glutelin $(\mathrm{RG})$ is the major storage protein in rice, which is an attractive candidate for a plant-based emulsifier, because of its low allergenicity, ability to reduce cholesterol 
24 al., 2003). Nevertheless, the application of native RG, as an emulsifier, is limited

because of its low water-solubility and poor surface activity. Therefore, the native protein must be modified to improve its solubility and emulsifying properties. Enzyme modification has proved to be an effective means of altering the molecular, physicochemical and functional properties of proteins (Avramenko, Low, \& Nickerson, 2013; Chen, Chen, Ren, \& Zhao, 2011). Limited enzyme hydrolysis of rice protein has been shown to improve its emulsifying properties by increasing its surface hydrophobicity and molecular flexibility (Paraman, Hettiarachchy, Schaefer, \& Beck, 2007). Recently, we examined the influence of the degree of enzyme hydrolysis on the ability of rice glutelin to form and stabilize emulsions. We found that the optimum emulsifying properties were obtained for the degree of hydrolysis as $2 \%$, and so a hydrolyzed rice glutelin (H-RG) ingredient with this level of hydrolysis was used in the current study.

In the current study, we compared the ability of H-RG to form and stabilize oil-in-water emulsions, and compared its performance to whey protein isolate (WPI), which is already a commonly used emulsifier in the food industry. In particular, we focused on the influence of environmental stresses that food products may experience during their manufacture, storage and utilization, such as $\mathrm{pH}$, ionic strength and temperature. This study therefore provides valuable information about the potential utilization of natural emulsifiers in the development of label-friendly emulsion-based food and beverage products. 


\section{Materials and methods}

\subsection{Materials}

Rice glutelin (93.42 wt\%, dry basis) was kindly provided by Golden Agriculture Biotech Company Limited (Jiangxi, China). Whey protein isolate (WPI) was purchased from Davisco Foods International Inc. (Le Sueur, MN). As stated by the manufacturer, the protein content was $97.6 \%$ (dry basis). Corn oil was obtained from a commercial food supplier (Mazola, ACH Food Companies, Memphis, TN). Double-distilled water was used throughout to prepare all solutions and emulsions.

\subsection{Preparation of rice glutelin hydrolysates}

Hydrolyzed protein was prepared using trypsin at an optimized enzyme/substrate ratio according to Zhao et al. (2012). $2 \mathrm{~g}$ of RG was added to double-distilled water (30 $\mathrm{ml}$ ) with constant stirring for $1 \mathrm{~h}$. After $\mathrm{pH}$ and temperature adjustments $\left(\mathrm{pH}=8,50{ }^{\circ} \mathrm{C}\right)$, trypsin was added. The $\mathrm{pH}$ of the suspension was kept constant by the addition of 2.5 $\mathrm{M} \mathrm{NaOH}$ during the entire period of hydrolysis. After $4.2 \mathrm{~min}$ of hydrolysis, the dispersion was heated to $95{ }^{\circ} \mathrm{C}$ for 10 min to inactivate the enzyme, followed by adjustment of the $\mathrm{pH}$ to 7.0 using $\mathrm{HCl}$ or $\mathrm{NaOH}$, and immediate cooling in water to room temperature. The mixture was centrifuged (TGL-20B, Anting Scientific Instrument Factory, Shanghai, China) at $4800 \mathrm{~g}$ for $10 \mathrm{~min}$, and the supernatant was freeze-dried. The degree of hydrolysis (DH) was calculated from the amount of base required to maintain a constant $\mathrm{pH}$ using the $\mathrm{pH}$-stat method described previously (Adler-Nissen, 1986): 


$$
\mathrm{DH}=\frac{h}{h_{t o t}} \times 100 \%=\frac{\mathrm{BN}_{\mathrm{b}}}{\alpha h_{t o t} \mathrm{M}_{p}} \times 100 \%
$$

of the protein; the value of $\alpha$ was 0.885 at $\mathrm{pH} 8$ and $50{ }^{\circ} \mathrm{C}$ treatment (Adler-Nissen,

1986; García-Moreno et al., 2014), and $\mathrm{h}_{\text {tot }}$ is the theoretical overall number of peptide bonds in the protein substrate $(7.40 \mathrm{meq} / \mathrm{g}$ rice protein) (Zhao et al., 2012). Rice glutelin with degree of hydrolysis of $2 \%$ was finally obtained.

\subsection{Characterization of rice protein and its hydrolysates}

\subsubsection{Sodium dodecyl sulphate polyacrylamide gel electrophoresis (SDS-PAGE)}

The polypeptide profiles of samples were determined by SDS-PAGE, as described previously (Laemmli, 1970). Protein samples were dissolved in loading buffer that contained $\beta$-mercaptoethanol (Solarbio, China) and were heated in boiling water for 5 min, then cooled to room temperature. $20 \mu \mathrm{l}$ of sample $(1 \mathrm{mg} / \mathrm{ml})$ was loaded on $5 \%$ stacking gel and $12.5 \%$ separating gel, and subjected to electrophoresis at a constant voltage of $80 \mathrm{~V}$. Then the gels were stained for $2 \mathrm{~h}$ using $0.05 \%$ Coomassie Brilliant Blue R-250 in acetic acid/methanol/water solution (46:227:227, v/v/v) and destained for $6 \mathrm{~h}$ with methanol/acetic acid/water solution $(50: 75: 875, \mathrm{v} / \mathrm{v} / \mathrm{v})$.

\subsubsection{Water-solubility}

The water-solubility of proteins was analyzed by measuring the protein content using the Lowry method (Lowry, Rosebrough, Farr, \& Randall, 1951) with bovine serum albumin as a standard. $1 \mathrm{wt} \%$ of protein aqueous solution was stirred magnetically at $25{ }^{\circ} \mathrm{C}$ for $30 \mathrm{~min}$, and the $\mathrm{pH}$ was then adjusted to the desired value 
using either $0.5 \mathrm{M} \mathrm{HCl}$ or $0.5 \mathrm{M} \mathrm{NaOH}$. After 30 min of stirring, the $\mathrm{pH}$ was readjusted if necessary. The dispersions were centrifuged at $4800 \mathrm{~g}$ for $15 \mathrm{~min}$, and the protein content in the supernatant was analyzed. After appropriate dilution, the protein solubility was calculated as the percentage of protein in the supernatant relative to the total protein content. All measurements were conducted in triplicate.

\subsection{Emulsion preparation}

Protein solutions were prepared by dispersing 0.01 to $8 \mathrm{wt} \%$ WPI or H-RG into phosphate buffer (5 mM pH 7.0), and were stirred for at least $3 \mathrm{~h}$. After overnight storage at $4{ }^{\circ} \mathrm{C}$, protein solutions were filtered with a qualitative filter (Fisher Scientific, PA) to remove any insoluble components. The absorbance at $280 \mathrm{~nm}$ of the protein solutions was measured before and after filtration, which indicated that a small amount of protein $(<2.5 \%$ of the total) was lost. $10 \mathrm{wt} \%$ oil phase (corn oil) and $90 \mathrm{wt} \%$ aqueous phase (protein in buffer) were homogenized using a high-shear mixer at 10,000 rpm for 2 min (M133/1281-0, Biospec Products, Inc., ESGC, Switzerland). The coarse emulsions were passed through a high pressure homogenizer (M110Y, Microfluidics, Newton, MA), with a $75 \mu \mathrm{m}$ interaction chamber (F20Y) and an operating pressure of $12,000 \mathrm{psi}$, for 3 times.

\subsection{Emulsion stability}

The stability of the emulsions was measured after they were subjected to environmental stresses that foods may experience during manufacture, storage and utilization. 
109 Freshly prepared emulsions ( $\mathrm{pH}$ 7) were distributed into different beakers, and then

110 each sample was adjusted to a different $\mathrm{pH}$ value, ranging from 2 to 8 using $\mathrm{HCl}$ or

$111 \mathrm{NaOH}$ solutions, and then placed in test tubes.

113 Freshly prepared emulsions $(\mathrm{pH} 7)$ were distributed into different beakers, and then

114 each sample was adjusted to a different ionic strength by adding different amounts of

$115 \mathrm{NaCl}$ solution, and then placed in test tubes.

\subsubsection{Temperature}

117 The temperature stability of freshly prepared emulsions ( $\mathrm{pH}$ 7) was measured.

118 Emulsions containing either 0 or $200 \mathrm{mM} \mathrm{NaCl}$ were transferred into test tubes, which

119 were then heated in water baths set at different temperatures $\left(30-90{ }^{\circ} \mathrm{C}\right)$ for $30 \mathrm{~min}$.

120 The test tubes were then cooled to room temperature by placing them in ice water.

121 After exposure to these environmental stresses, samples were stored at room

122 temperature for $24 \mathrm{~h}$ prior to determination of their particle size and $\zeta$-potential, and for

1237 days prior to visual observation.

\subsection{Droplet size and particle charge ( $\zeta$-potential) measurement}

The particle size distribution was determined using a laser diffraction instrument

126 (Mastersizer 2000, Malvern Instruments Ltd., Malvern, Worcestershire, UK).

127 Emulsions were diluted with the appropriate buffer solutions (same $\mathrm{pH}$ as sample being

128 analyzed) to avoid multiple scattering effects, and stirred at $1200 \mathrm{rpm}$ to ensure

129 complete dispersion. The mean particle diameter is reported as the surface-weighted 
mean diameter $\left(d_{32}\right)$, since this is inversely related to the specific surface area of the

131 droplets.

132 The $\zeta$-potential of the emulsions was measured using a particle electrophoresis

133 instrument at $25^{\circ} \mathrm{C}$ (Zetasizer Nano ZS series, Malvern Instruments, Worcestershire,

134 UK). For the emulsions, the samples were diluted 100-fold with the appropriate buffer

135 (same $\mathrm{pH}$ as sample) to avoid multiple scattering during measurements. The refractive

136 indices used were 1.33 for buffer and 1.47 for corn oil.

138 Each experiment was performed in triplicate, and the results are reported as means

139 values \pm standard deviation (SD). Significant differences between means $(p<0.05)$ were

140 calculated by one-way ANOVA test using statistical analysis software (SPASS 19.0,

141 SPSS Inc., Chicago, IL).

\section{Results and discussion}

\subsection{Characterization of rice protein and its hydrolysates}

\subsubsection{SDS-PAGE analysis}

SDS-PAGE was performed to investigate differences in the composition of rice

146 glutelin before and after hydrolysis. Under reducing conditions, RG mainly exhibited

147 two clear bands, one that was about $20 \mathrm{kDa}$, namely alkaline $\beta$-subunit, and another one

148 around $33 \mathrm{kDa}$, namely acidic $\alpha$-subunit (Figure 1). Another faint band was observed

149 around $53 \mathrm{kDa}$, which can be attributed to the presence of covalently linked $\alpha$ - and

$150 \beta$-polypeptides. This result is in accordance with that reported previously on this

151 protein (Likitwattanasade \& Hongsprabhas, 2010), where it was reported that the major 
protein subunits of $\mathrm{RG}$ were around 20,30 and $50 \mathrm{kDa}$. molecular weight peptides. These results are in accordance with those reported

156 previously (Avramenko, Low, \& Nickerson, 2013; Ghribi, Gafsi, Sila, Blecker,

157 Danthine, Attia, et al., 2015), where it was reported that enzyme hydrolysis cleaved

158 peptide bonds within individual or aggregated proteins to produce smaller peptides or

159 protein subunits. A change in protein structure would be expected to have a significant 160 influence on protein functional properties, such as water-solubility and emulsifying 161 properties.

\subsubsection{Water-solubility}

163 The water-solubility of proteins is an important prerequisite for many of their

164 functional attributes. As shown in Figure 2, the solubility-pH profiles of both native and

165 hydrolyzed glutelin were U-shaped, with minimum solubility values around $\mathrm{pH} 5$ and $166 \mathrm{pH} 4$ for $\mathrm{RG}(2.2 \%)$ and $\mathrm{H}-\mathrm{RG}(66.7 \%)$, respectively. This reduction in protein 167 solubility at intermediate $\mathrm{pH}$ values can be attributed to a decrease in the magnitude of 168 the electrostatic repulsion between the protein molecules around their isoelectric points 169 (pI) (Du, Jiang, Zhu, Xiong, Shi, Hu, et al., 2012; Sarkar, Kamaruddin, Bentley, \& 170 Wang, 2016). Previous studies have also reported a shift in the pI of proteins after 171 partial hydrolysis, which can be attributed to a change in the nature of anionic and 172 cationic groups exposed at the polypeptide surfaces (Jamdar, Rajalakshmi, Pednekar, 173 Juan, Yardi, \& Sharma, 2010; Ochiai, Kamata, \& Shibasaki, 1982). In general, the 
174 solubility of the hydrolyzed protein was much higher than that of the native protein.

175 The poor water-solubility of the native protein can be attributed to the existence of a

176 rigid polypeptide structure, with subunits linked by high amounts of intermolecular and

177 intramolecular disulfide bonds and hydrophobic interactions (Paraman, Hettiarachchy,

178 \& Schaefer, 2007). In our study, the solubility of H-RG was significantly higher than

179 that of $\mathrm{RG}$ at all $\mathrm{pH}$ values $(p<0.05)$. Similar results have been reported after partial

180 hydrolysis of other types of glutelin, such as corn glutelin (Zheng, Wang, Liu, Sun,

181 Zheng, Wang, et al., 2015) and barley glutelin (Xia, Bamdad, Gänzle, \& Chen, 2012).

182 The improved solubility of H-RG was attributed to the reduction in molecular weight,

183 the unfolding of the polypeptide chains, and the release of soluble aggregates from

184 insoluble aggregates or precipitates (Ghribi, et al., 2015). A reduction in the molecular

185 dimensions of the proteins could also lead to a decrease in the van der Waals attraction,

186 as well as an increase in entropy of mixing effects, both of which would favour an

187 increase in solubility.

\subsection{Influence of emulsifier type and concentration on emulsion formation}

The ability of the hydrolyzed rice glutelin to form stable oil-in-water emulsions

was evaluated by comparing its performance to a well-established protein-based

191 emulsifier: whey protein isolate (WPI). Emulsions were formed by passing oil (10 wt\%)

192 and aqueous phase (90 wt \%) through a microfluidizer at high pressure. The influence

193 of initial emulsifier concentration on the mean particle diameter of the emulsions

194 produced was determined.

195 For both emulsifiers, the mean particle diameter $\left(d_{32}\right)$ decreased as the emulsifier 
199 profiles could be divided into two regions (Charoen, Jangchud, Jangchud, Harnsilawat,

200 Naivikul, \& McClements, 2011; Jafari, Assadpoor, He, \& Bhandari, 2008). In region I,

$201 d_{32}$ progressively decreased with increasing emulsion concentration. In this region, the

202 homogenizer is capable of generating smaller droplets, but the minimum droplet size

203 achievable is limited by the total amount of emulsifier present to cover the surfaces of

204 the droplets. In region II, the droplet size remains relatively constant, as there is enough

205 emulsifier present to cover all the droplet surfaces but the homogenizer is not capable

206 of producing any smaller droplets under the operating conditions used (Qian, Decker,

207 Xiao, \& McClements, 2011). The mean particle diameters achieved were fairly similar

208 for both emulsifiers at the higher emulsion concentrations used, which is likely because

209 the droplet size was limited by the homogenizer disruptive energy rather than by the

210 emulsifier type (Ozturk, Argin, Ozilgen, \& McClements, 2014). Nevertheless, the

211 droplet diameter versus the emulsifier concentration profiles were different, which was

212 probably due to a combination of factors related to emulsifier type: the rate of

213 emulsifier adsorption; the reduction in interfacial tension; the modification of

214 interfacial rheology; and the strength of the repulsive interactions between droplets

215 (Jafari, Assadpoor, He, \& Bhandari, 2008; Schubert \& Engel, 2004).

216 For many applications of food emulsions, the shape of the particle size 217 distribution is important. Multimodal distributions were observed below $0.5 \mathrm{wt} \%$ WPI 
and $2 \% \mathrm{H}-\mathrm{RG}$, whereas monomodal distributions were observed at higher emulsifier

219 levels (Figure 3b-c). Visual observation of emulsions containing relatively low levels

220 of emulsifier indicated that they were highly susceptible to rapid creaming (data not

221 shown), which can be attributed to the relatively large size of the droplets they

222 contained. From a practical and economic standpoint, it is important to use

223 sufficient emulsifier to form an emulsion containing small droplets, without having

224 too much excess emulsifier in the aqueous phase (Ozturk, Argin, Ozilgen, \&

225 McClements, 2015). The droplet diameter versus the emulsifier concentration profiles

226 indicated that this level was around $1 \mathrm{wt} \%$ for WPI $\left(d_{32}=167.5 \mathrm{~nm}\right)$ and around $3 \mathrm{wt} \%$

227 for $\mathrm{H}-\mathrm{RG}\left(d_{32}=150.0 \mathrm{~nm}\right)$. For the remainder of the studies we therefore utilized

228 these levels to form the emulsions.

229 The surface load $(\Gamma)$ of an emulsifier is an important indicator of its effectiveness

230 at forming emulsions. The surface load is the mass of emulsifier required to cover a

231 unit area of droplet surface $\left(\mathrm{mg} / \mathrm{m}^{2}\right)$, and is given by the following equation (Dickinson,

232 1992; Mcclements, 2007; Ozturk, Argin, Ozilgen, \& McClements, 2015):

$$
\Gamma=\frac{C s \cdot d_{32}}{6 \varphi}
$$

where $\mathrm{C}_{\mathrm{S}}$ is the concentration of adsorbed emulsifier present $\left(\mathrm{kg} / \mathrm{m}^{3}\right), d_{32}$ is the

235 mean droplet diameter produced $(\mathrm{m})$, and $\varphi$ is the disperse phase volume fraction. In

236 our experiments, $\varphi$ was about 0.1 (10\% oil), $d_{32}$ was $167.5 \mathrm{~nm}$ (WPI) or $159.0 \mathrm{~nm}$

237 (H-RG), and $\mathrm{C}_{\mathrm{S}}$ was $10 \mathrm{~kg} / \mathrm{m}^{3}$ (1 wt $\%$ WPI) or $30 \mathrm{~kg} / \mathrm{m}^{3}$ (3 wt $\left.\% \mathrm{H}-\mathrm{RG}\right)$. Therefore, the 238 surface load of WPI $\left(\Gamma \approx 2.79 \mathrm{mg} / \mathrm{m}^{2}\right)$ was about 2.8 times smaller than that of $\mathrm{H}-\mathrm{RG}(\Gamma$ $239 \approx 7.95 \mathrm{mg} / \mathrm{m}^{2}$ ). This difference can be attributed to the different molecular weights 
and packing of the proteins adsorbed to the droplet surfaces. From a practical viewpoint,

241 this means that more $\mathrm{H}-\mathrm{RG}$ is required to produce an emulsion with a given fat content 242 and droplet size than WPI.

\subsection{Influence of environmental conditions on emulsion stability}

Practically, emulsion-based foods should remain stable during processing, storage,

245 transportation, and utilization. Food emulsifiers must therefore be able to stabilize

246 emulsions when they are exposed to the environmental conditions typical of a

247 particular product type, such as $\mathrm{pH}$, ionic strength, or temperature changes. We

248 therefore investigated the influence of $\mathrm{pH}$, ionic strength, and thermal processing on the

249 physical stabilities of emulsions stabilized by $1 \%$ WPI or $3 \%$ H-RG.

\subsubsection{Influence of $\mathrm{pH}$}

The influence of $\mathrm{pH}$ on the $\zeta$-potential, particle size, and creaming stability of

252 emulsions stabilized by the two different proteins was measured (Figure 4). The

$253 \zeta$-potential of both emulsions went from highly positive at $\mathrm{pH} 2(+26.9$ and $+37.1 \mathrm{mV}$

254 for $\mathrm{H}-\mathrm{RG}$ and WPI, respectively) to highly negative at $\mathrm{pH} 8(-40.7$ and $-48.8 \mathrm{mV}$ for

255 H-RG and WPI, respectively), with a point of zero charge around $\mathrm{pH} 4.2$ and 4.8 for

256 H-RG and WPI, respectively (Figure 4a). The magnitude of the $\zeta$-potential on H-RG

257 was slightly lower than that of WPI at both high and low $\mathrm{pH}$ values, which might be

258 ascribed to differences in the number of anionic and cationic groups they contain. When

259 the $\mathrm{pH}$ value was higher than the $\mathrm{pI}$ of protein, the carboxyl groups (- $\left.\mathrm{COO}^{-}\right)$were

260 negative and the amino groups $\left(-\mathrm{NH}_{2}\right)$ were neutral. Conversely, when the $\mathrm{pH}$ was

261 appreciably lower than the pI, the carboxyl groups were neutral $(-\mathrm{COOH})$ and the 
amino groups were positive $\left(\mathrm{NH}_{3}{ }^{+}\right)$.

The stability of the emulsions to droplet aggregation and creaming was highly pH-dependent (Figure 4b). For WPI, the droplets were stable to aggregation and creaming at relatively low ( $\mathrm{pH} 2$ to 3 ) and high ( $\mathrm{pH} 6$ to 8) $\mathrm{pH}$ values, but highly unstable at intermediate $\mathrm{pH}$ values. This effect can be attributed to the reduction in the magnitude of the $\zeta$-potential on the droplets at $\mathrm{pH}$ values around the isoelectric point of the droplets (Figure 4a). As a result, the electrostatic repulsion between the droplets is no longer sufficient to overcome the attractive van der Waals and hydrophobic interactions (McClements, 2004). For H-RG, the emulsions were only stable to aggregation and creaming at relatively high (pH 7 and 8) pH values, and were highly unstable at lower $\mathrm{pH}$ values. The extensive amount of droplet aggregation observed in these emulsions at low $\mathrm{pH}$ values was surprising, since the relatively large $\zeta$-potential $(+27 \mathrm{mV})$ on the droplets would be expected to generate a strong electrostatic repulsion.

This effect may have been due to the fact that the emulsions were initially prepared at $\mathrm{pH} 7$, and then adjusted to other $\mathrm{pH}$ values. Consequently, some irreversible droplet aggregation may have occurred when the H-RG-coated droplets passed through the isoelectric point, whereas only reversible aggregation occurred for the WPI-coated droplets. Irreversible aggregation may have occurred due to the formation of strong hydrophobic or disulfide bonds when the droplets came into close proximity. It should also be noted that there might be differences in the isoelectric point of adsorbed and non-adsorbed proteins in emulsions, due to differences in the number and type of ionized groups exposed to the surrounding aqueous phase. 
The magnitude of the $\zeta$-potential of both emulsions decreased with increasing salt

286 concentration (Figure 5a). This effect can be attributed to the accumulation of 287 counter-ions $\left(\mathrm{Na}^{+}\right)$around anionic groups $\left(-\mathrm{CO}_{2}^{-}\right)$on the droplet surfaces, thereby 288 reducing their net charge, due to electrostatic screening effects. Furthermore, the ionic 289 strength had an appreciable effect on droplet aggregation (Figure 5b). For WPI, there 290 was a slight increase in the mean particle diameter at the highest salt levels used (300 291 and $500 \mathrm{mM}$ ), suggesting that a limited amount of droplet aggregation had occurred. 292 For example, $d_{32}$ increased from about $0.163 \mu \mathrm{m}$ at $0 \mathrm{mM} \mathrm{NaCl}$ to $0.292 \mu \mathrm{m}$ at $500 \mathrm{mM}$ $293 \mathrm{NaCl}$. For H-RG, the increase in mean particle diameter was much greater at higher 294 salt levels. For example, in this case, $d_{32}$ increased from around $0.159 \mu \mathrm{m}$ at $0 \mathrm{mM}$ $295 \mathrm{NaCl}$ to $3.53 \mu \mathrm{m}$ at $500 \mathrm{mM} \mathrm{NaCl}$. The destabilization of protein-coated oil droplets at 296 high salt levels can mainly be attributed to screening of the electrostatic interactions 297 between them (McClements, 2004), as suggested by the reduction in $\zeta$-potential (Figure 298 5a). At low $\mathrm{NaCl}$ concentrations the electrostatic repulsive forces acting between the 299 droplets are strong enough to overcome any attractive forces (e.g., van der Waals and 300 hydrophobic), thereby inhibiting droplet aggregation (Yang, Leser, Sher, \& 301 McClements, 2013). On the contrary, at sufficiently high $\mathrm{NaCl}$ levels the attractive 302 forces are larger than the electrostatic repulsive forces, thereby leading to droplet 303 aggregation (Qian, Decker, Xiao, \& McClements, 2011). In addition, high levels of 304 salt may alter the solubility of the proteins and peptides in the H-RG (Xu, Liu, \& 305 Zhang, 2015), which may cause them to aggregate and alter their ability to form and 
stabilize emulsions. Overall, our results show that WPI-coated oil droplets are more

307 stable at high ionic strength conditions than H-RG-coated ones. This may have

308 occurred for a number of reasons: WPI-coated droplets had higher $\zeta$-potential leading

309 to stronger electrostatic repulsion; WPI formed thicker interfacial layers than

310 hydrolyzed rice glutelin leading to stronger steric repulsion; H-RG-coated droplets had

311 higher surface hydrophobicity leading to a stronger hydrophobic attraction.

\subsubsection{Influence of temperature}

313 The influence of heat treatment $\left(30-90^{\circ} \mathrm{C}, 30 \mathrm{~min}\right)$ on the mean particle diameter

314 and $\zeta$-potential of the emulsions was also examined in the absence or presence of salt (0

315 or $200 \mathrm{mM} \mathrm{NaCl}$ ). The upper level of $\mathrm{NaCl}$ was selected because both the WPI and

316 H-RG emulsions were relatively stable to droplet aggregation at this salt content at

317 room temperature (Figure 5b). The salt was added before the emulsions were thermally

318 processed, because this reduces the electrostatic repulsion between the droplets during

319 heating, which is known to potentially reduce their stability to aggregation (Qian,

320 Decker, Xiao, \& McClements, 2011).

321 In the absence of salt, the emulsions prepared using either WPI or H-RG were both

322 stable to heat treatment across the entire temperature range investigated, with no

323 appreciable change in the mean particle diameter or visible evidence of phase

324 separation (data not shown). For example, the mean particle diameters were only about

3250.163 and $0.167 \mu \mathrm{m}$ for WPI and $\mathrm{H}-\mathrm{RG}$ emulsions, respectively, after heating to $90{ }^{\circ} \mathrm{C}$.

326 This suggests that both types of emulsifiers had good heat stability when the emulsions

327 were thermally processed in the absence of added salt. The origin of this stability can 
328 be attributed to the high electrostatic repulsion between the oil droplets at low salt

329 levels. Thus, the repulsive interactions (electrostatic and steric) are strong enough to

330 overcome any attractive interactions (van der Waals and hydrophobic).

331 In the presence of salt $(200 \mathrm{mM})$, the surface charge for both emulsions showed

332 no significant change after heat treatment over the temperature range studied (Figure

333 6a). This suggests that there was little alteration in the number or location of the

334 charged groups at the droplet surfaces induced by heating. The WPI-stabilized

335 emulsions remained stable to aggregation when they were held at temperatures of 70

$336{ }^{\circ} \mathrm{C}$ or less, but they became highly unstable when they were heated to higher

337 temperatures (Figure 6b). For example, the mean particle diameter increased from

338 around $0.22 \mu \mathrm{m}$ at $70{ }^{\circ} \mathrm{C}$ to around $33 \mu \mathrm{m}$ at $90{ }^{\circ} \mathrm{C}$. The H-RG-stabilized emulsions

339 only remained stable to aggregation when they were held at temperatures of $50{ }^{\circ} \mathrm{C}$ or

340 less, but underwent extensive droplet aggregation when heated to higher temperatures.

341 For example, the mean particle diameter increased from around $0.34 \mu \mathrm{m}$ at $50{ }^{\circ} \mathrm{C}$ to

342 around $10.4 \mu \mathrm{m}$ at $90{ }^{\circ} \mathrm{C}$. In addition, there was clear evidence of phase separation in

343 the samples, in the test tubes, held at higher temperatures $\left(>50^{\circ} \mathrm{C}\right)$, with a droplet-rich

344 cream layer at the top and a droplet-depleted serum layer at the bottom.

345 The decrease in the aggregation stability of the emulsions when they were heated

346 above a certain temperature in the presence of salt can be attributed to a change in the

347 nature of the colloidal interactions in the system. Upon heating, the adsorbed globular

348 proteins undergo a conformational change, which leads to exposure of non-polar and

349 sulfhydryl groups, that are normally imbedded in the hydrophobic interior of the 
350 protein (Day, Zhai, Xu, Jones, Hoffmann, \& Wooster, 2014; Kim, Decker, \&

351 McClements, 2002). Consequently, the surface hydrophobicity of the oil droplets

352 increased, which generate a strong hydrophobic attraction between the droplets. In the

353 presence of salt, the attractive interactions (van der Waals and hydrophobic) are then

354 strong enough to overcome the repulsive interactions (steric and electrostatic), which

355 led to droplet aggregation. The fact that the WPI-coated droplets could be heated to a

356 higher temperature than the H-RG-coated ones before aggregation was observed,

357 suggests that there were differences in their thermal denaturation $\left(\mathrm{T}_{\mathrm{m}}\right)$ temperatures

358 (Sarkar, Kamaruddin, Bentley, \& Wang, 2016). Previously it has been reported that

359 the thermal denaturation temperature of native rice glutelin is around $82.2{ }^{\circ} \mathrm{C}(\mathrm{Ju}$,

360 Hettiarachchy, \& Rath, 2001) and that of WPI was around $75^{\circ} \mathrm{C}$ (Fitzsimons, Mulvihill,

361 \& Morris, 2007). The transition temperatures and enthalpy of denaturation of

362 hydrolyzed proteins have also been reported to be lower than that of the native form

363 (Wani, Sogi, Shivhare, \& Gill, 2015). Consequently, the thermal denaturation

364 temperature of hydrolyzed rice glutelin may have been lower than that reported for

365 the native form. This phenomenon would then account for the fact that the

366 WPI-coated droplets were stable over a wider temperature range than the

367 H-RG-coated ones.

368 In summary, the above experiments indicate that $\mathrm{H}-\mathrm{RG}$ emulsions were stable 369 over a range of environmental conditions: $\mathrm{pH}$ 6-8 $\left(0 \mathrm{mM} \mathrm{NaCl}, 25^{\circ} \mathrm{C}\right) ; \mathrm{NaCl} \leq 200 \mathrm{mM}$

$370\left(\mathrm{pH} 7,25^{\circ} \mathrm{C}\right)$; temperatures $\leq 90^{\circ} \mathrm{C}$ in the absence of salt $(\mathrm{pH} 7,0 \mathrm{mM} \mathrm{NaCl})$;

371 temperatures $\leq 50{ }^{\circ} \mathrm{C}$ in the presence of salt $(\mathrm{pH} 7,200 \mathrm{mM} \mathrm{NaCl})$ studied. However, 
372 the emulsions were highly unstable to aggregation at lower $\mathrm{pH}$ values, higher ionic 373 strengths, and elevated temperatures. Consequently, there is a need to develop effective

374 strategies to improve the stability of emulsions containing H-RG-coated droplets.

\section{Conclusions}

In this study, we compared the functional performance of hydrolyzed rice

377 glutelin (H-RG) to that of whey protein isolate (WPI), which is a commonly used

378 dairy protein. The main factors influencing the formation and stability of emulsions

379 produced using either H-RG or WPI as protein-based emulsifiers were studied. The

380 emulsifier content significantly influenced the stability of emulsions showing

381 decrease of mean particle diameter with increasing emulsifier concentration. Both

382 emulsifiers could be used to form oil-in-water emulsions containing relatively small

383 droplets $(d<200 \mathrm{~nm})$, but a smaller amount of WPI was required than H-RG. Indeed,

384 the surface load of $\mathrm{H}-\mathrm{RG}\left(\Gamma \approx 7.95 \mathrm{mg} / \mathrm{m}^{2}\right)$ was almost three times higher than that of

385 WPI $\left(\Gamma \approx 2.79 \mathrm{mg} / \mathrm{m}^{2}\right)$. In addition, WPI provided better stability to environmental

386 stresses, such as $\mathrm{pH}$ changes, high ionic strengths, and heating, than H-RG. Further

387 research is therefore needed to improve the stability of emulsions formed by H-RG so

388 that it can be used in a wide range of food products.

\section{$389 \quad$ Acknowledgements}

390 This study was supported by the Freedom Explore Program of State Key

391 Laboratory of Food Science and Technology of Nanchang University (No. 392 SKLF-ZZB-201512), and the National Natural Science Foundation of China (Nr 393 31271953). We would also like to thank Chinese Research Council scholarship 
394 program for providing funding for Xingfeng Xu. This material was also partly based 395 upon work supported by the Cooperative State Research, Extension, Education Service, 396 USDA, Massachusetts Agricultural Experiment Station (MAS00491) and USDA, NRI 397 Grants (2011-67021, 2013-03795, and 2014-67021).

\section{$398 \quad$ References}

399 Adler-Nissen, J. (1986). Enzymic hydrolysis of food proteins: Elsevier Applied Science Publishers.

401

Agboola, S., Ng, D., \& Mills, D. (2005). Characterisation and functional properties of Australian rice protein isolates. Journal of Cereal Science, 41(3), 283-290.

Avramenko, N. A., Low, N. H., \& Nickerson, M. T. (2013). The effects of limited enzymatic hydrolysis on the physicochemical and emulsifying properties of a lentil protein isolate. Food Research International, 51(1), 162-169.

Charoen, R., Jangchud, A., Jangchud, K., Harnsilawat, T., Naivikul, O., \& McClements, D. J. (2011). Influence of Biopolymer Emulsifier Type on Formation and Stability of Rice Bran Oil-in-Water Emulsions: Whey Protein, Gum Arabic, and Modified Starch. Journal of Food Science, 76(1), E165-E172.

Chen, L., Chen, J., Ren, J., \& Zhao, M. (2011). Modifications of soy protein isolates using combined extrusion pre-treatment and controlled enzymatic hydrolysis for improved emulsifying properties. Food hydrocolloids, 25(5), 887-897.

Chrastil, J. (1992). Correlations between the physicochemical and functional properties of rice. Journal of Agricultural and Food Chemistry, 40(9), 1683-1686.

Day, L., Zhai, J. L., Xu, M., Jones, N. C., Hoffmann, S. V., \& Wooster, T. J. (2014). 

interfaces examined by Synchrotron Radiation Circular Dichroism. Food hydrocolloids, 34(1), 78-87.

Dickinson, E. (1992). An Introduction to Food Colloids. In): Oxford University Press: Oxford, UK.

Dickinson, E. (2003). Hydrocolloids at interfaces and the influence on the properties of dispersed systems. Food Hydrocolloids, 17(1), 25-39.

Do, A. B., Williams, K., \& Toomer, O. T. (2016). In vitro digestibility and immunoreactivity of bovine milk proteins. Food Chemistry, 190, 581-587.

Du, Y., Jiang, Y., Zhu, X., Xiong, H., Shi, S., Hu, J., Peng, H., Zhou, Q., \& Sun, W.

Du, Y., Shi, S., Jiang, Y., Xiong, H., Woo, M. W., Zhao, Q., Bai, C., Zhou, Q., \& Sun, W. Chemistry, 133(3), 923-929.

Fitzsimons, S. A., Mulvihill, D. M., \& Morris, E. R. (2007). Denaturation and aggregation processes in thermal gelation of whey proteins resolved by differential scanning calorimetry. Food hydrocolloids, 21(4), 638-644.

Fiocchi, A., Travaini, M., D'Auria, E., Banderali, G., Bernardo, L., \& Riva, E. (2003). Tolerance to a rice hydrolysate formula in children allergic to cow's milk and 
García-Moreno, P. J., Batista, I., Pires, C., Bandarra, N. M., Espejo-Carpio, F. J., Guadix, A., \& Guadix, E. M. (2014). Antioxidant activity of protein Research International, 65, 469-476.

Ghribi, A. M., Gafsi, I. M., Sila, A., Blecker, C., Danthine, S., Attia, H., Bougatef, A., \& Besbes, S. (2015). Effects of enzymatic hydrolysis on conformational and functional properties of chickpea protein isolate. Food Chemistry, 187, 322-330.

Jafari, S. M., Assadpoor, E., He, Y., \& Bhandari, B. (2008). Re-coalescence of emulsion droplets during high-energy emulsification. Food hydrocolloids,

Jamdar, S., Rajalakshmi, V., Pednekar, M., Juan, F., Yardi, V., \& Sharma, A. (2010). Influence of degree of hydrolysis on functional properties, antioxidant activity

Ju, Z. Y., Hettiarachchy, N. S., \& Rath, N. (2001). Extraction, denaturation and hydrophobic properties of rice flour proteins. Journal of Food Science, 66(2),

Khouryieh, H., Puli, G., Williams, K., \& Aramouni, F. (2015). Effects of xanthanlocust bean gum mixtures on the physicochemical properties and oxidative stability of whey protein stabilised oil-in-water emulsions. Food Chemistry, 167, 
461 Kim, H. J., Decker, E. A., \& McClements, D. J. (2002). Role of postadsorption conformation changes of beta-lactoglobulin on its ability to stabilize oil droplets against flocculation during heating at neutral pH. Langmuir, 18(20), 7577-7583.

Laemmli, U. K. (1970). Cleavage of structural proteins during the assembly of the head of bacteriophage T4. nature, 227(5259), 680-685.

Likitwattanasade, T., \& Hongsprabhas, P. (2010). Effect of storage proteins on pasting properties and microstructure of Thai rice. Food Research International, 43(5), 1402-1409.

Lowry, O. H., Rosebrough, N. J., Farr, A. L., \& Randall, R. J. (1951). Protein measurement with the Folin phenol reagent. The Journal of Biological Chemistry, 193(1), 265-275.

McClements, D. J. (2004). Protein-stabilized emulsions. Current Opinion in Colloid \& Interface Science, 9(5), 305-313.

Mcclements, D. J. (2007). Critical review of techniques and methodologies for characterization of emulsion stability. Critical Reviews in Food Science and Nutrition, 47(7), 611-649.

Ochiai, K., Kamata, Y., \& Shibasaki, K. (1982). Effect of tryptic digestion on emulsifying properties of soy protein. Agricultural and Biological Chemistry, 46(1), 91-96.

Ozturk, B., Argin, S., Ozilgen, M., \& McClements, D. J. (2014). Formation and stabilization of nanoemulsion-based vitamin E delivery systems using natural 

57-63.

Ozturk, B., Argin, S., Ozilgen, M., \& McClements, D. J. (2015). Formation and stabilization of nanoemulsion-based vitamin E delivery systems using natural biopolymers: Whey protein isolate and gum arabic. Food Chemistry, 188, 256-263.

Paraman, I., Hettiarachchy, N., \& Schaefer, C. (2007). Glycosylation and deamidation of rice endosperm protein for improved solubility and emulsifying properties. Cereal Chemistry, 84(6), 593-599.

Paraman, I., Hettiarachchy, N., Schaefer, C., \& Beck, M. I. (2007). Hydrophobicity, solubility, and emulsifying properties of enzyme-modified rice endosperm protein. Cereal Chemistry, 84(4), 343-349.

Qian, C., Decker, E. A., Xiao, H., \& McClements, D. J. (2011). Comparison of biopolymer emulsifier performance in formation and stabilization of orange oil-in-water emulsions. Journal of the American Oil Chemists' Society, 88(1), 47-55.

Sarkar, A., Kamaruddin, H., Bentley, A., \& Wang, S. (2016). Emulsion stabilization by tomato seed protein isolate: Influence of $\mathrm{pH}$, ionic strength and thermal treatment. Food Hydrocolloids, 57, 160-168.

Schubert, H., \& Engel, R. (2004). Product and formulation engineering of emulsions. Chemical Engineering Research and Design, 82(9), 1137-1143.

Wani, I. A., Sogi, D. S., Shivhare, U. S., \& Gill, B. S. (2015). Physico-chemical and 
functional properties of native and hydrolyzed kidney bean (Phaseolus vulgaris L.) protein isolates. Food Research International, 76, 11-18.

Xia, Y., Bamdad, F., Gänzle, M., \& Chen, L. (2012). Fractionation and characterization of antioxidant peptides derived from barley glutelin by enzymatic hydrolysis. Food Chemistry, 134(3), 1509-1518.

Xu, H. N., Liu, Y., \& Zhang, L. F. (2015). Salting-out and salting-in: competitive effects of salt on the aggregation behavior of soy protein particles and their emulsifying

Yang, Y., Leser, M. E., Sher, A. A., \& McClements, D. J. (2013). Formation and stability of emulsions using a natural small molecule surfactant: Quillaja saponin (Q-Naturale®). Food Hydrocolloids, 30(2), 589-596.

Zhao, Q., Xiong, H., Selomulya, C., Chen, X. D., Zhong, H., Wang, S., Sun, W., \& Zhou, Q. (2012). Enzymatic hydrolysis of rice dreg protein: Effects of enzyme type on the functional properties and antioxidant activities of recovered proteins. hydrolysis time on the physicochemical and functional properties of corn glutelin by Protamex hydrolysis. Food Chemistry, 172, 407-415. 


\section{Figure Captions:}

Figure 1. SDS-PAGE of rice glutelin and its hydrolysates in the presence of $\beta$-mercaptoethanol.

Figure 2. Water-solubility of RG and $\mathrm{H}-\mathrm{RG}$ at different $\mathrm{pH}$.

Figure 3a. Influence of protein type and concentration on mean droplet diameter $\left(\mathrm{d}_{3,2}\right)$ of emulsions stabilized by WPI and H-RG.

Figure 3b. Influence of protein type and concentration on the particle size distribution of WPI emulsions.

Figure 3c. Influence of protein type and concentration on the particle size distribution of H-RG emulsions.

Figure 4. Influence of $\mathrm{pH}(2-7)$ on $\zeta$-potential (a) and the mean particle diameter $\left(\mathrm{d}_{3,2}\right)$ (b) of corn oil-in water emulsions stabilized by WPI and H-RG.

Figure 5. Influence of $\mathrm{NaCl}(0-500 \mathrm{mM})$ on $\zeta$-potential (a) and the mean particle diameter (b) of corn oil-in-water emulsions stabilized by WPI and H-RG.

Figure 6. Influence of temperature $\left(30-90^{\circ} \mathrm{C}\right)$ on $\zeta$-potential (a) and the mean particle diameter (b) of corn oil-in-water emulsions stabilized by WPI and H-RG in the presence of $200 \mathrm{mM} \mathrm{NaCl}$. 
Figure 1

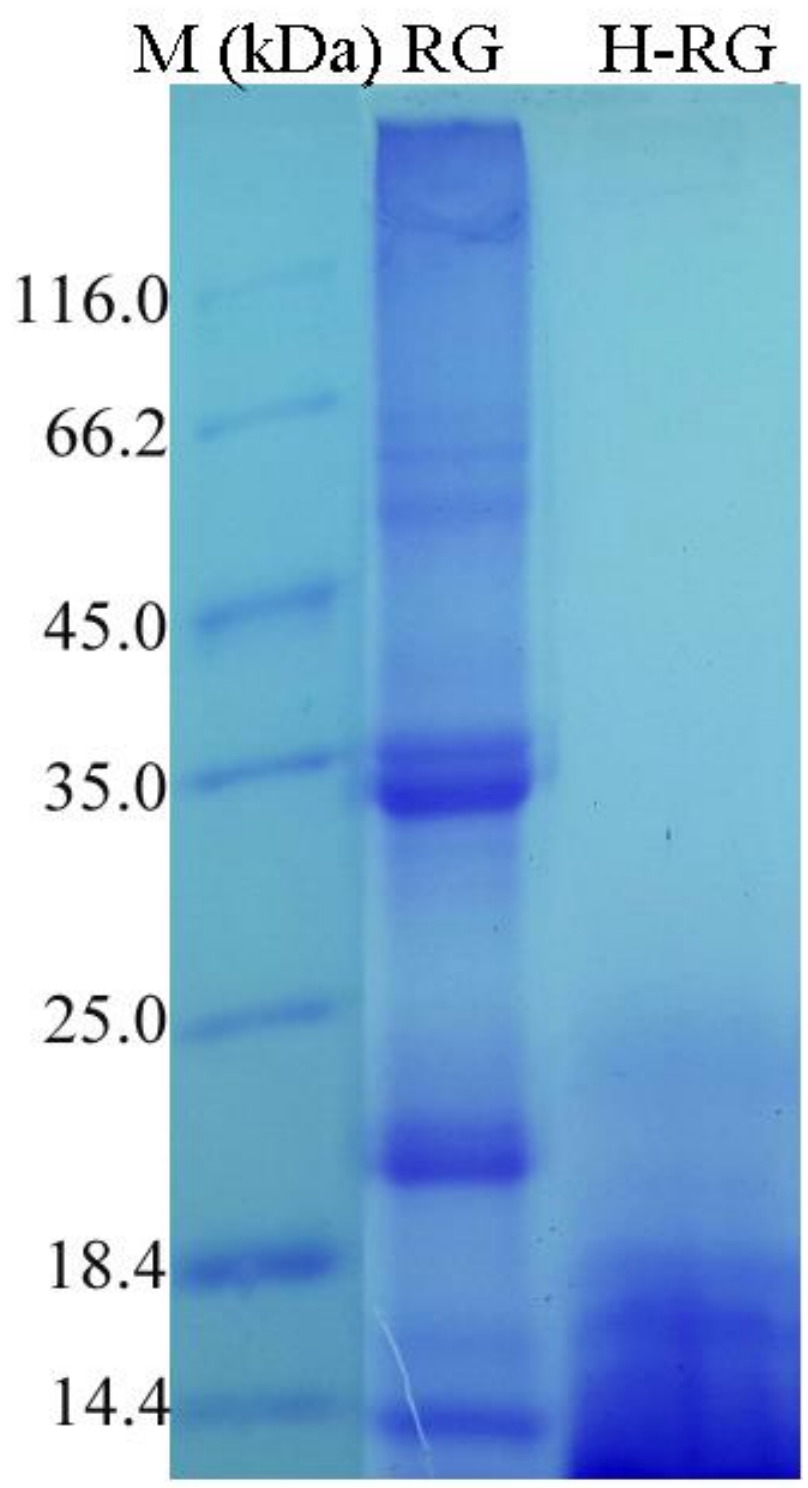


Figure 2

(b)

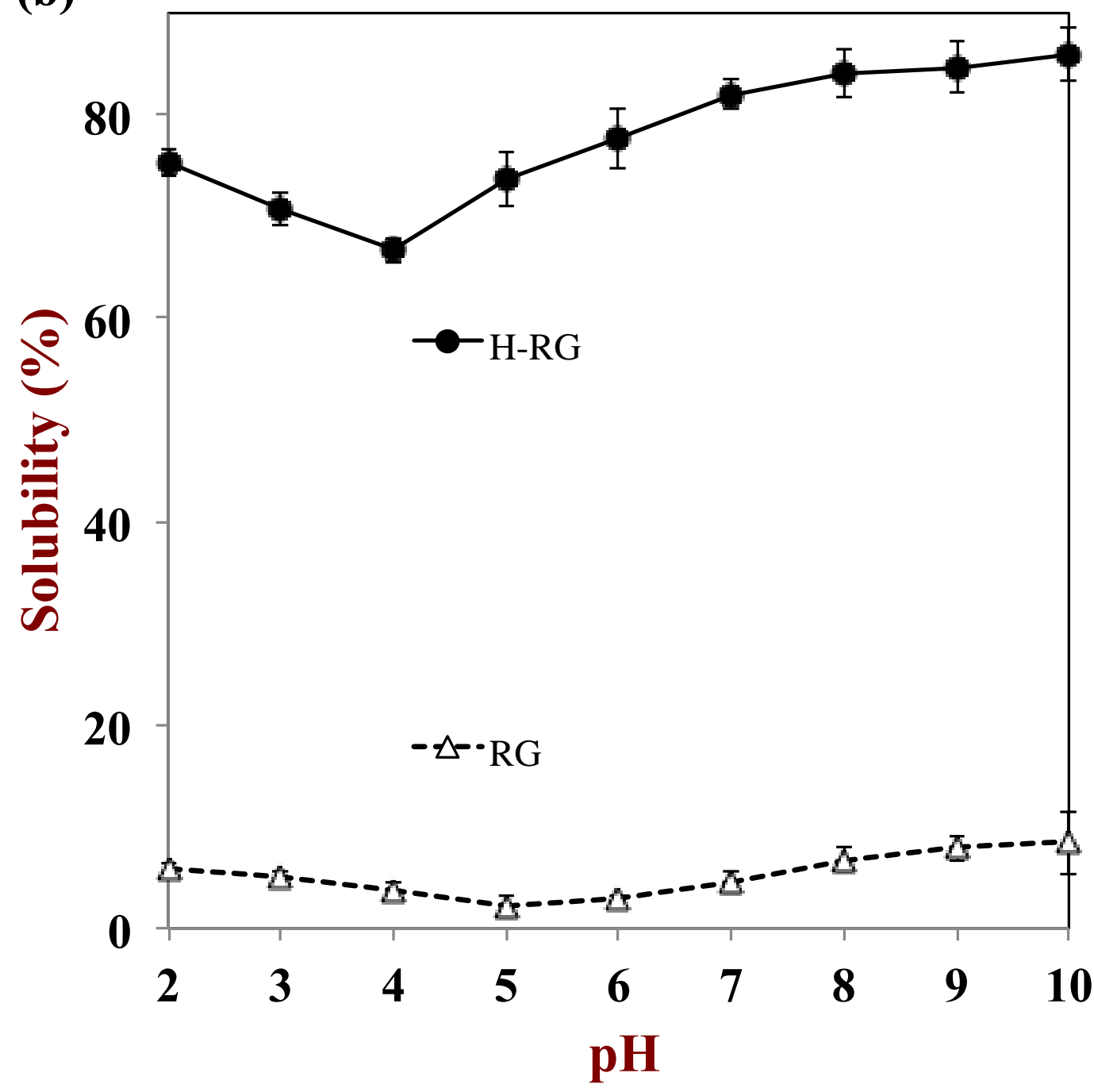


Figure 3a

(a)

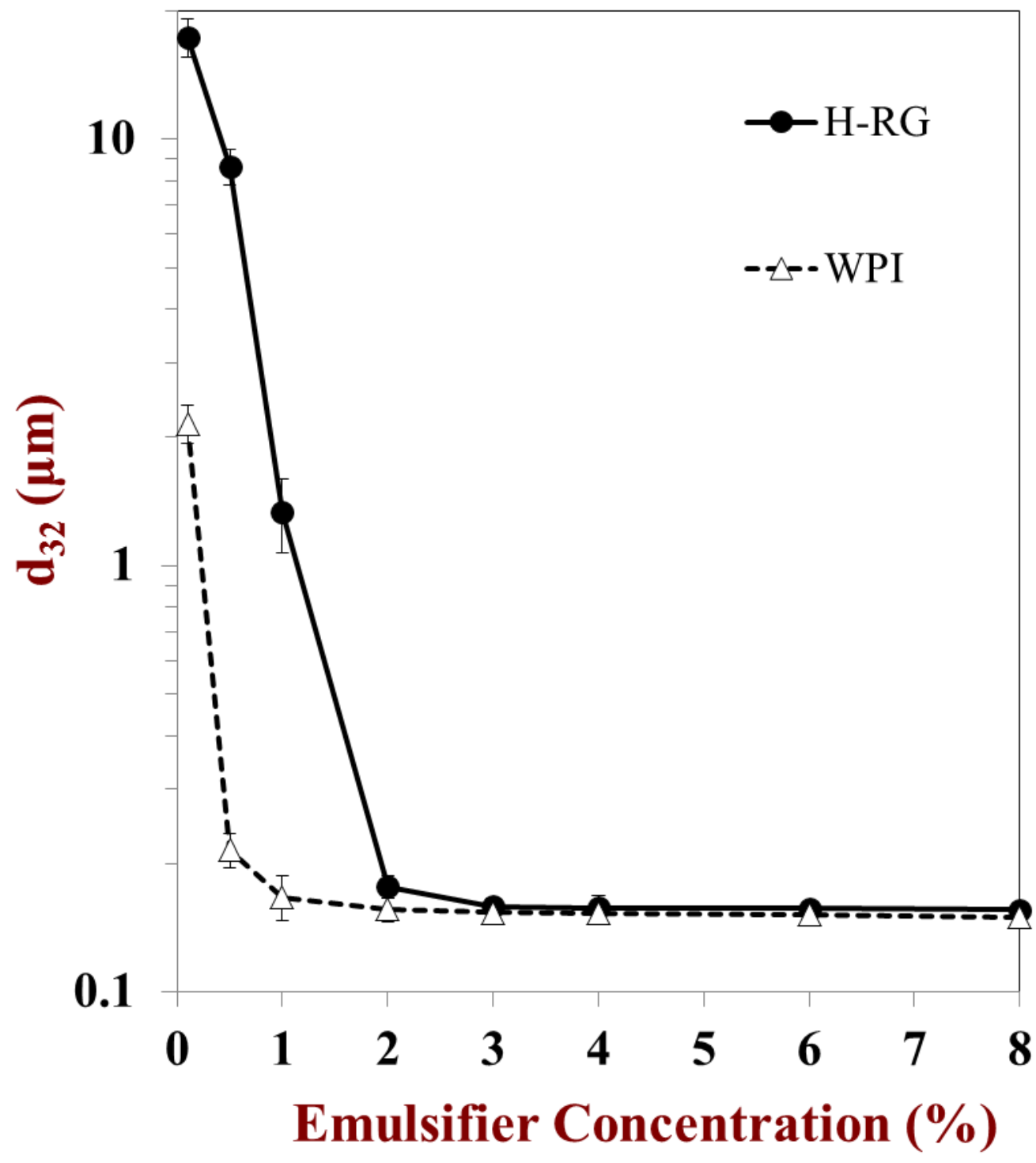


Figure 3b

(b)

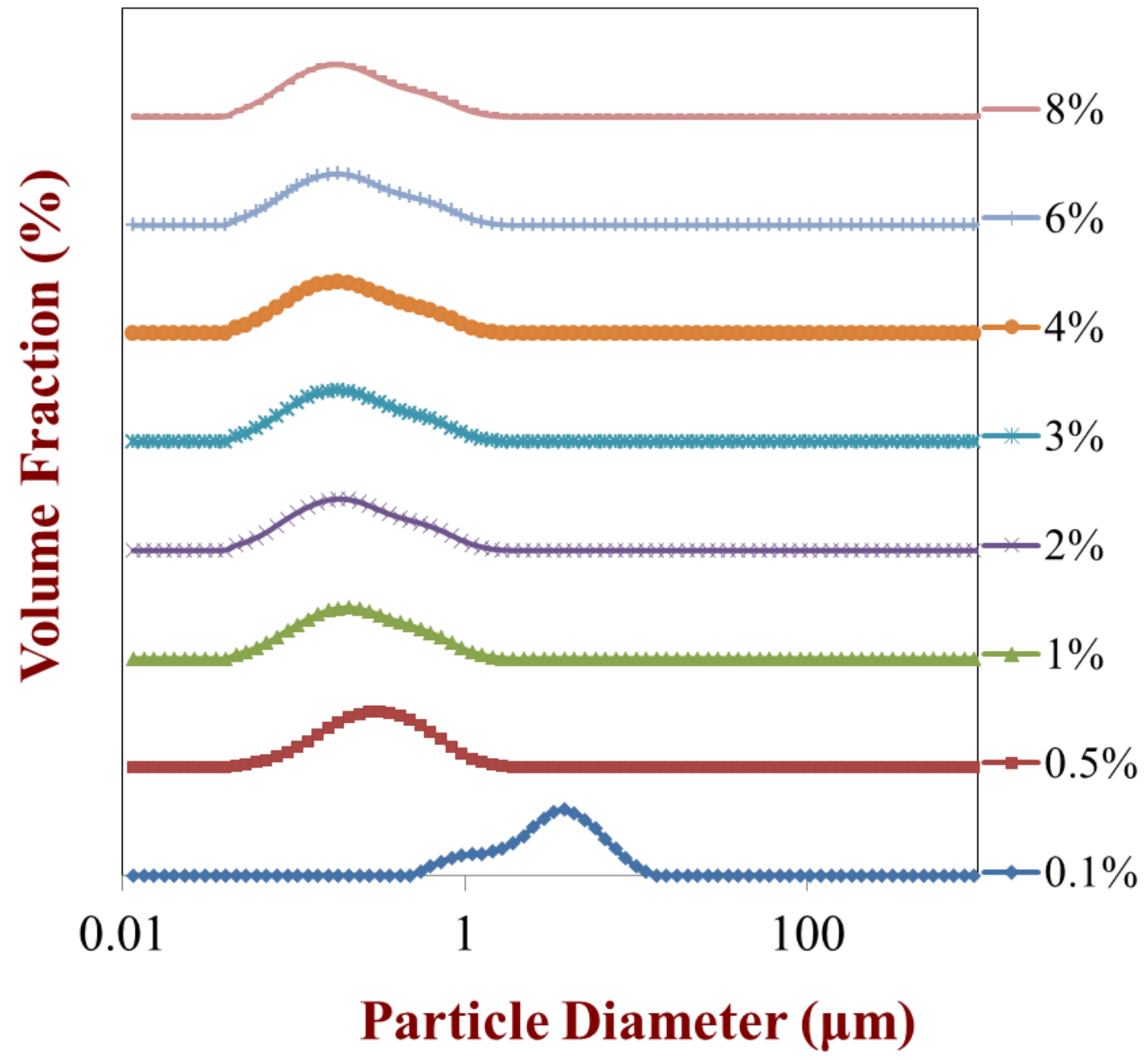


Figure 3c

(c)

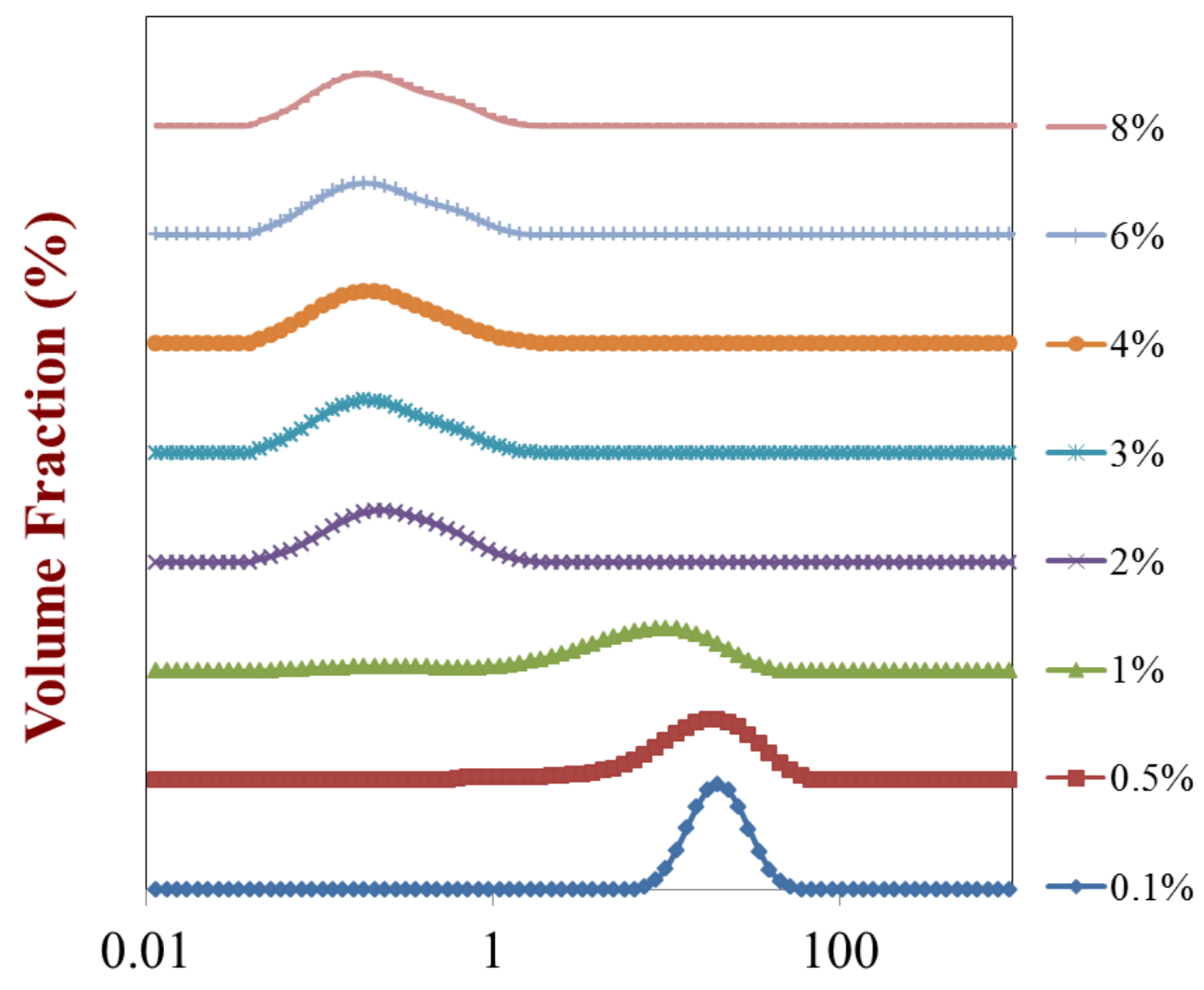

Particle Diameter $(\mu \mathrm{m})$ 
Figure 4a

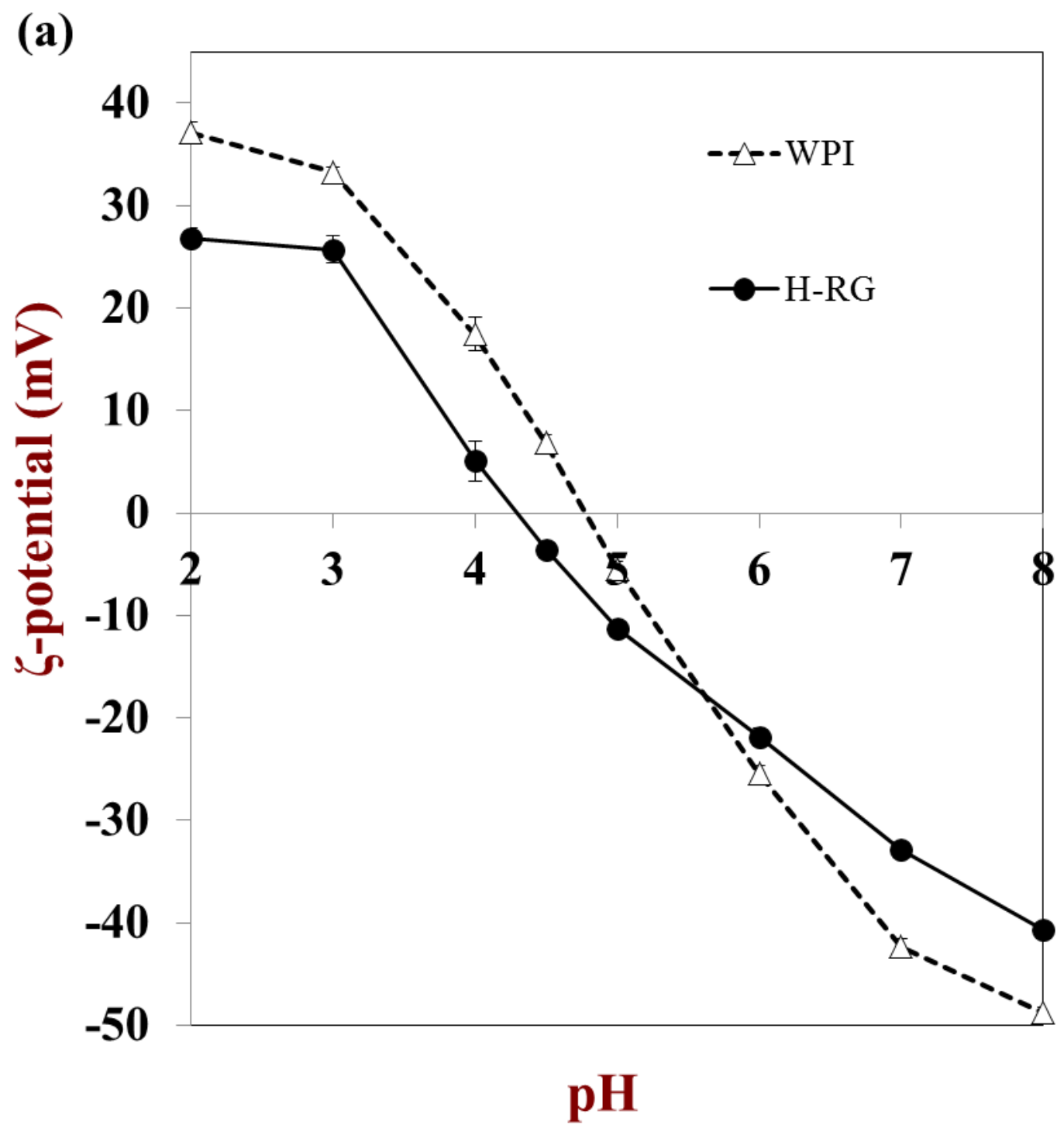


Figure 4b

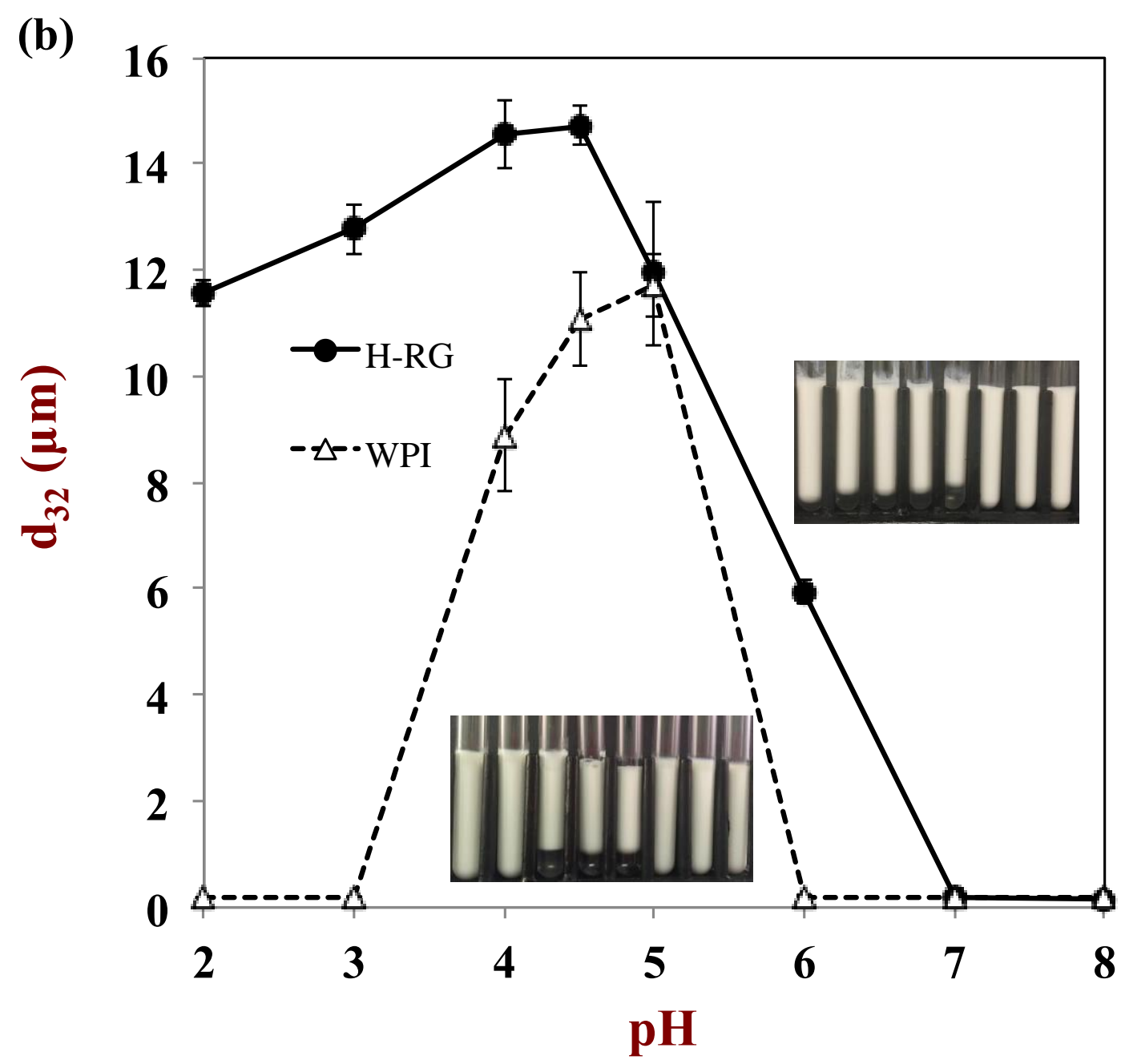


Figure 5a

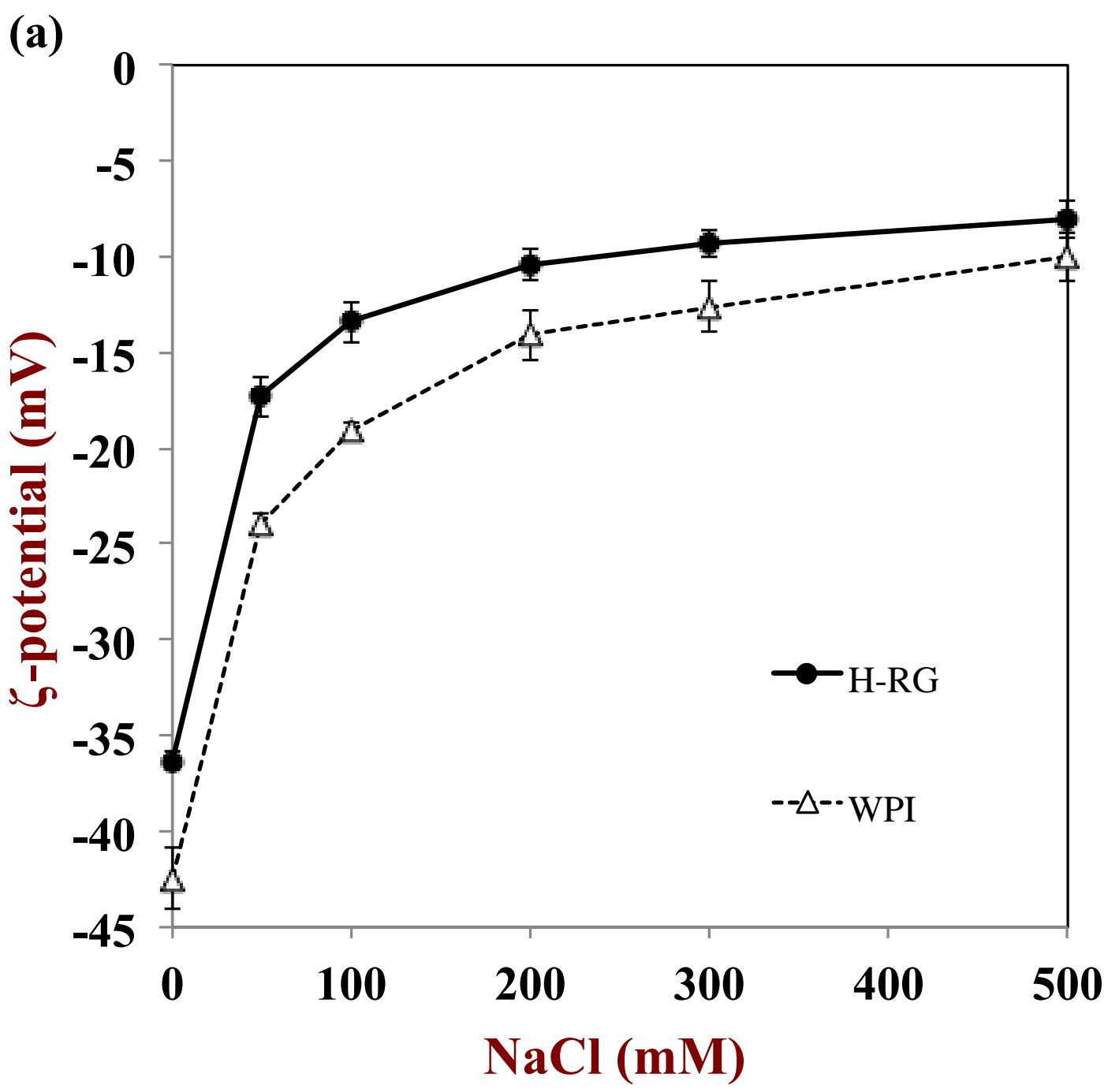


Figure 5b

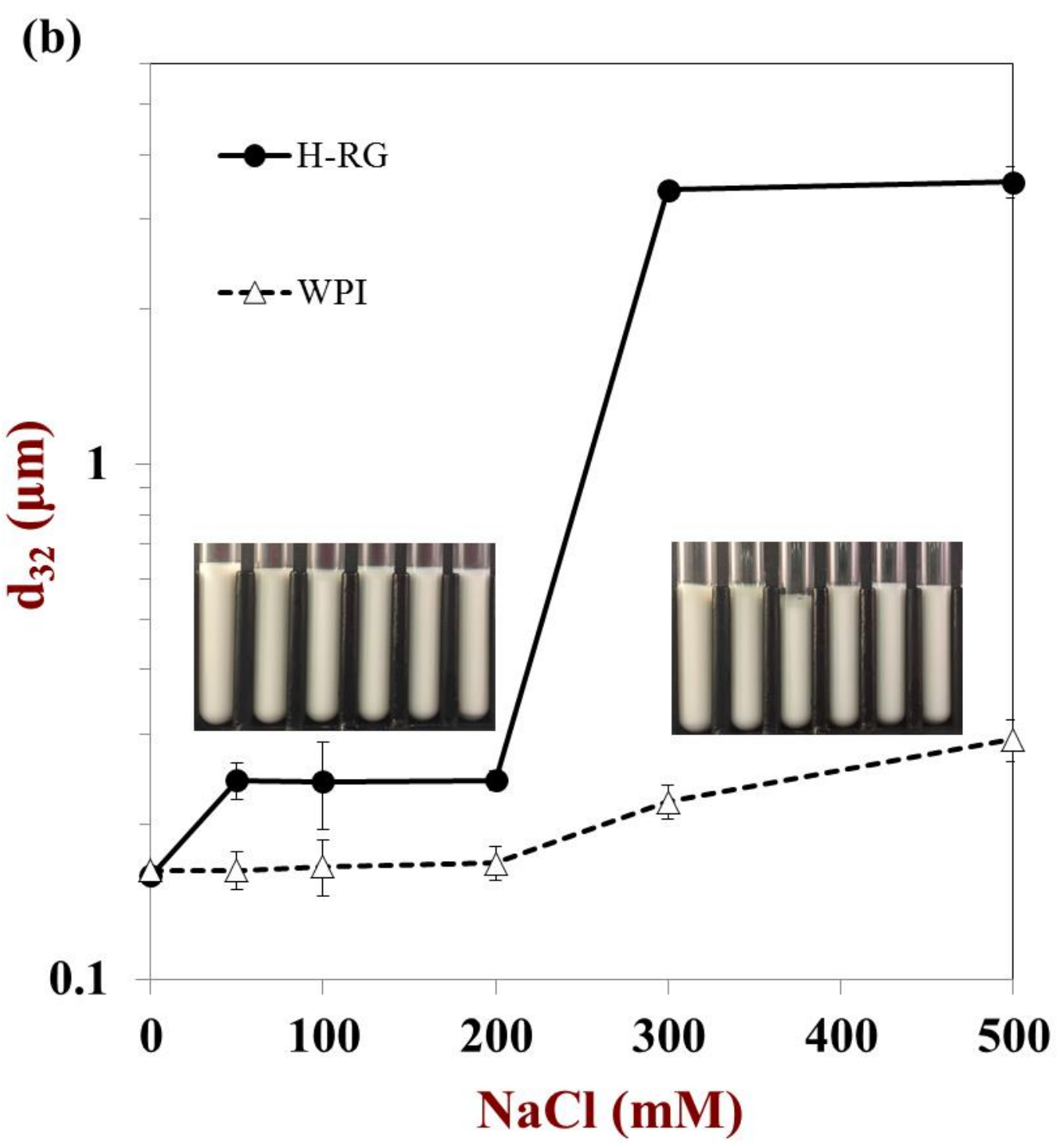


Figure 6a

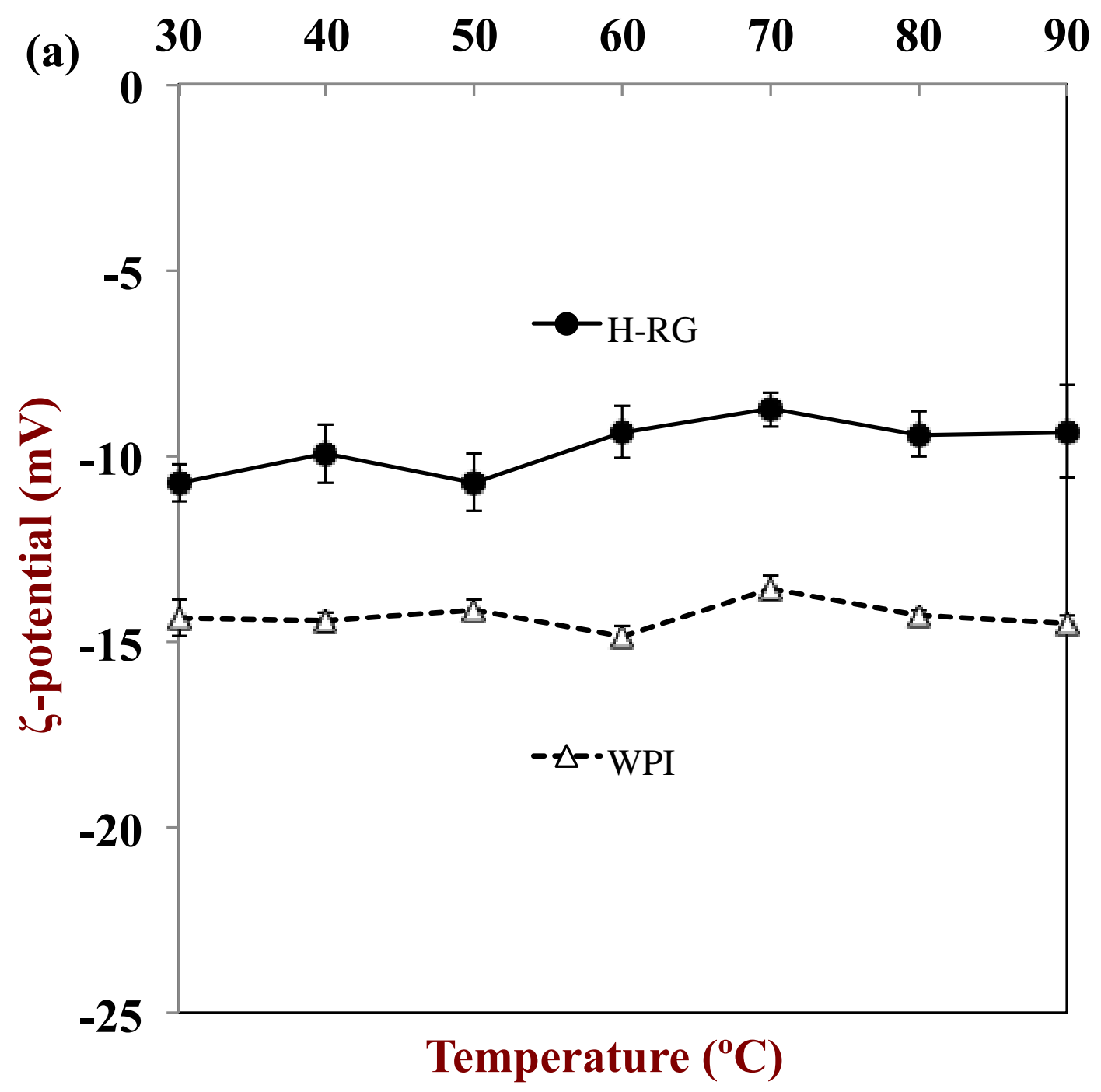


Figure 6b

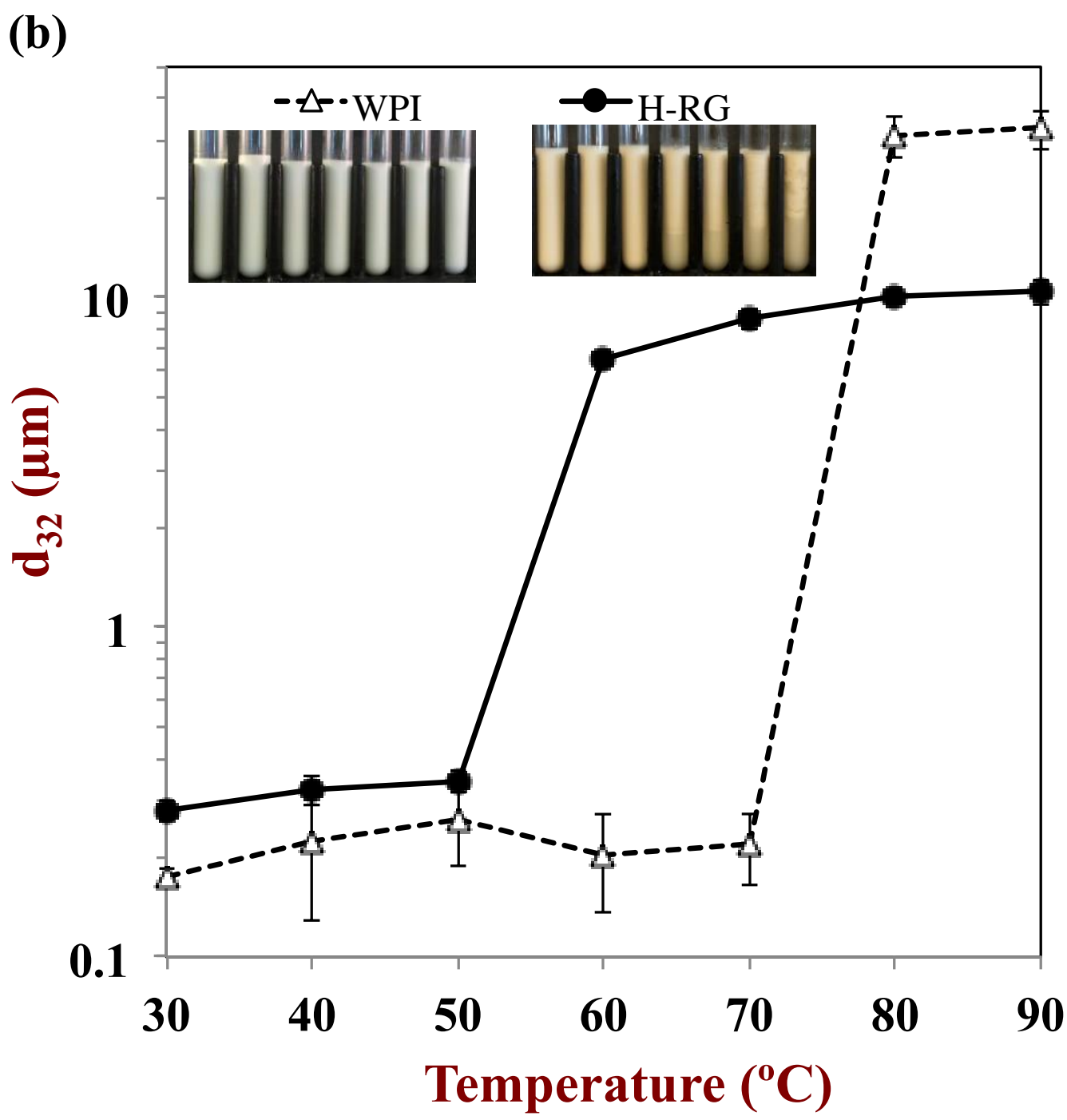

